\title{
Sciatica due to Lumbar Intraspinal Gas Pseudocyst
}

\author{
Ali Akhaddar, Brahim Eljebbouri, Okacha Naama and Mohammed Boucetta
}

Key words: epidural gas, intraspinal gas, lumbar disc herniation, nerve root compression, sciatica

(Intern Med 49: 2647, 2010)

(DOI: 10.2169/internalmedicine.49.4474)
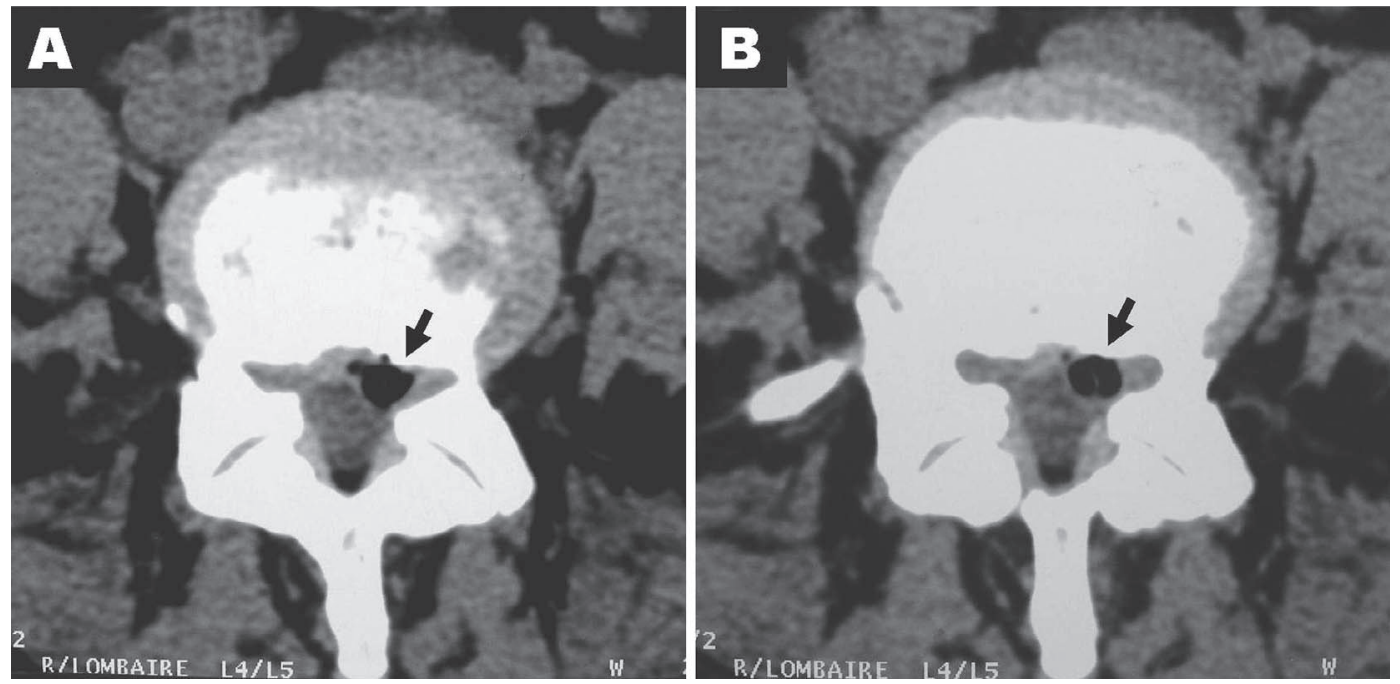

Picture 1.

A 37-year-old previously healthy woman presented with a 6-month history of left radicular leg pain. She denied any precipitating factor and had no history of excessive motion or sports before the onset of clinical symptoms. Physical examination showed a positive straight leg raising at $60^{\circ}$ without motor weakness. The right side was normal. Computed tomography revealed moderate disc protrusion at L4-L5 and a $6 \mathrm{~mm}$ epidural gas bubble (arrows) below the intervertebral disc space compressing the left L5 nerve root (Picture $1 \mathrm{~A}$ and $1 \mathrm{~B}$ ). An ipsilateral L4-L5 interlaminar approach was performed with enlargement of the lateral recess. The $\mathrm{L}$ 5 nerve root appeared swollen and compressed by the adjacent pseudo-cyst that was removed. No disc material was seen. Histopathological diagnosis of the removed tissue revealed nonspecific fibrous tissue. Postoperatively, the radicular symptoms were significantly diminished without recurrence.

Epidural gas pseudocyst is a rare intraspinal lesion that has been suggested to originate from the intervertebral disc due to the motion of the spine (1). The gas is composed primarily of nitrogen and is often trapped within a thin layer of nonspecific fibrous tissue membrane identical to the posterior longitudinal ligament (1-3). Often asymptomatic, clinical symptoms can be similar to those of other more common causes of lumbar radiculopathy $(1,2)$. Surgery is indicated when conservative therapy fails.

\section{References}

1. Kakitsubata Y, Theodorou SJ, Theodorou DJ, et al. Symptomatic epidural gas cyst associated with discal vacuum phenomenon. Spine 34: E784-E789, 2009.

2. Cheng TM, Link MJ, Onofrio BM. Pneumatic nerve root compression: epidural gas in association with lateral disc herniation. Report of two cases. J Neurosurg 81: 453-458, 1994.

3. Yoshida H, Shinomiya K, Nakai O, Kurosa Y, Yamaura I. Lumbar nerve root compression caused by lumbar intraspinal gas. Report of three cases. Spine 22: 348-351, 1997.

Department of Neurosurgery, Mohammed V Military Teaching Hospital, Mohammed V Souissi University, Rabat, Morocco

Received for publication September 2, 2010; Accepted for publication September 8, 2010

Correspondence to Dr. Ali Akhaddar, akhaddar@hotmail.fr

(C) 2010 The Japanese Society of Internal Medicine Journal Website: http://www.naika.or.jp/imindex.html 